\title{
Ethnocentrism In Icelandic Consumers And Its Consequences
}

\author{
Soumava Bandyopadhyay, Lamar University, USA
}

\begin{abstract}
This paper presents an empirical test to measure consumer ethnocentrism in Iceland. The wellknown measure of consumer ethnocentrism, the CETSCALE, is applied and its psychometric properties examined in the Icelandic context. The relationship of consumer ethnocentrism with various product country-of-origin attitudes is explored. The influence of ethnocentrism, country image, and perceptions of product quality, value, image, availability, and promotion on Icelandic consumers' intention to buy packaged food products made domestically and those imported from the United States, the United Kingdom, Holland, and Denmark is also investigated.
\end{abstract}

Keywords: Consumer Ethnocentrism; Country-of-Origin; International Marketing; Consumer Behavior; Iceland

\section{INTRODUCTION}

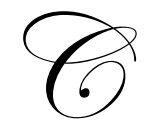

onsumer ethnocentrism is defined (Shimp and Sharma, 1987, p.280) as "the beliefs held by consumers about the appropriateness, indeed morality, of purchasing foreign-made products." Consumers who are ethnocentric believe that purchasing imported products is unpatriotic, causes loss of jobs, and hurts the domestic economy. Consumers who are non-ethnocentric judge foreign products on their merit without consideration of where these products are made. Ethnocentrism, therefore, is likely to be a factor in a consumers' preference for domestic products over imported products.

Consumers' evaluation of a product is influenced by the country associated with the product (Klein, Ettenson, and Morris, 1998). There is a substantial body of research on consumers' evaluation of products based on the country of origin, or COO (Chattalas, Kramer, and Takada, 2008). People tend to have stereotypical notions concerning products and people of other countries, and real product evaluations are almost always influenced by country stereotyping (Tse and Gorn, 1993; Papadopoulos and Heslop, 1993; Schneider, 2005). Many COO studies conducted in countries such as the United States (Shimp and Sharma, 1987; Suh and Kwon, 2002), Germany (Evanschitzky et al., 2008), Netherlands (Josiassen, 2011), Australia (Poon, Evangelista, and Albaum, 2010) and South Korea (Sharma, Shimp, and Shin, 1995; Suh and Kwon, 2002) have illustrated that consumers with ethnocentric tendencies have a proclivity to evaluate domestic products unreasonably favorably compared to imported products. This indicates a definite positive association between ethnocentrism and the evaluation of products made domestically, and a negative association between ethnocentrism and the evaluation of imported products (Vida and Reardon, 2008).

In this study, we report an empirical test to measure consumer ethnocentrism in Iceland. Although consumer ethnocentrism has been measured in several other countries (Klein, Ettenson, and Krishnan, 2006), no such measurement has yet been reported from Iceland. Iceland has a tiny population of 318,000, but it is a highly developed and affluent market, as indicated by the current per capita Gross National Income (GNI) of $\$ 33,870$ (World Bank, 2011). A competitive and deregulated business environment broadly in line with European legislation under the European Economic Area (EEA) agreement provides foreign marketers, particularly those from Europe, wide access to the Icelandic market (Lundberg, 1992). However, there is also some evidence of nationalistic and protectionist sentiments putting a leash on the extent of free international trade practiced by Iceland. Mainly to protect its own fishing interests, which conflict with the fishing policies of the European Union (EU), Iceland declined to be a full member of the European Union (EU) for many years (Katsioloudes, Thoradottir, and Balsmeier, 1996). In July, 2010, however, Iceland began talks on joining the EU as a full member (Tait, 2010). Upon being 
granted full member status, Iceland will have to open up its domestic market even further to the other EU countries. For the year 2010, Iceland had a balance of trade surplus of 34,061 million Icelandic Krona (about 300 million U.S. dollars), and this might be reduced after Iceland's market is opened up further to foreign competition (Statistics Iceland, 2011).

Considering the above facts, it would be interesting to explore ethnocentrism in Icelandic consumers and the extent to which the ethnocentrism may shape Icelandic consumers' evaluation of products imported from other countries based on COO attitudes. The most well-known scale that measures consumers' ethnocentric tendencies is the CETSCALE, developed by Shimp and Sharma (1987). In our study, the CETSCALE was applied in a survey distributed to consumers in Iceland. The 17-item CETSCALE was first formulated and rigorously validated in the United States. Although originally developed as a measure of American consumers' ethnocentric tendencies, the CETSCALE was subsequently applied and its psychometric properties validated internationally in many countries (Shankarmahesh, 2006). Our application of the CETSCALE in Iceland adds to the measure's cross-cultural relevance.

Besides examining the psychometric properties of the CETSCALE, this study also explores whether ethnocentrism in Icelandic consumers affects the perceived image of the home country as well as that of the United States, the United Kingdom, Holland, and Denmark (four major trading partners of Iceland), and whether the country images in turn influence the evaluation of products that are domestically-made and those that are imported from these four countries. Finally, the influence of ethnocentrism, country image, and various product and marketing related variables (such as perceived quality, value, image, availability, and promotion) on Icelandic consumers' intention to buy products made in Iceland and those imported from the four other countries is investigated by means of a regression model.

\section{RESEARCH DESIGN}

The sampling frame for the study comprised consumers in Reykjavik, the largest city in Iceland, which is home to about half of the country's population. The subjects in the sample were given a self-administered questionnaire that included two main sections. One section consisted of Shimp and Sharma's (1987) 17-item CETSCALE (with references to the United States in the original scale replaced with references to Iceland and the items translated into Icelandic). The individual scale items are listed in the Appendix. The respondents were asked to indicate their extent of agreement with various statements describing ethnocentric proclivities on a 7-point Likert scale $(1=$ strongly disagree, $7=$ strongly agree $)$. The other section consisted of scales to measure Icelandic consumers' perceptions regarding the quality ( 4 items), value (i.e., price relative to quality, 2 items), image (2 items), availability ( 2 items), promotional intensity ( 2 items), and the intention to buy ( 1 item) food products originating in the United States, the United Kingdom, Holland, Denmark, and Iceland, and scales to measure Icelandic consumers' general attitudes toward the five countries (i.e., country image, 3 items) in terms of economic and health-related factors. The items in the second section were adapted mainly from the established COO measure formulated by Pisharodi and Parameswaran (1992). The respondents were again asked to indicate on a 7-point Likert scale $(1=$ strongly disagree, $7=$ strongly agree $)$ their extent of agreement with statements on the quality, value, image, availability, promotion of and the intention to buy food products from the five countries as well as general characteristics of these five countries. All scale items are listed in the Appendix.

A specific product category (i.e., food) was selected for the study because the product category is likely to be a salient factor in product COO evaluations (Papadopoulos and Heslop, 1993). Food is a universally consumed product category that all consumers can identify with and, particularly for Icelandic consumers, food products might invoke specifically ethnocentrism-related evaluative criteria since Iceland's dilemma regarding joining the European Union has been mainly influenced by the country's need to protect its fishing interests (fish being a food and fishing being the most critical element of Iceland's economy).

The survey was distributed among 200 randomly selected consumers residing in Reykjavik, Iceland's largest city. A total of 72 usable responses were received, resulting in a net response rate of 36 percent, which is reasonable for survey research involving consumers. The average age and the median age of the respondents were 36.85 years and 36 years, respectively. Forty-eight of the 72 respondents $(66.7 \%)$ were male and $24(33.3 \%)$ were female. 


\section{RESULTS}

\section{Ethnocentrism}

The 17-item consumer ethnocentrism measure (CETSCALE) exhibited a high degree of internal consistency, as evidenced from a Cronbach's alpha reliability score of .895 . All individual scale items had statistically significant (at the $\mathrm{p}<.05$ level) item-to-total correlations. The psychometric properties of the CETSCALE from the Icelandic study are presented in Table 1. A principal components analysis of the 17 items resulted in the emergence of a single factor (with all item loadings being significant at the $\mathrm{p}<.05$ level) that accounted for 38.89 percent of the variance. To further test the unidimensionality of the CETSCALE, a set of confirmatory factor analyses were run using the covariance matrix of the 17 items as input (Durvasula, Andrews, and Netemeyer, 1997) via the LISREL 8 (Jöreskog and Sörbom, 1993) software package. Several measures were used to test the fit of the one-factor model. The chi-square of the of the one-factor model $\left(\chi^{2}=266.91, \mathrm{p}<.01\right)$ provides a significantly better fit than that of the null model that assumes no relationships $\left(\chi^{2}=650.23, \mathrm{p}<.01\right)$. Carmines and McIver (1981) suggested a Chi-square / degrees of freedom ratio of 3 or less as an acceptable level of fit for confirmatory factor models. This ratio was quite acceptable at 2.24 for the Icelandic sample. Other fit indices from the LISREL 8 output were reasonable - a goodness of fit index (GFI) of .65, an adjusted goodness of fit index (AGFI) of .55, and a low root mean square residual (RMSR) of .12. These results established the unidimensionality of the CETSCALE in Iceland.

Table 1

Properties of the CETSCALE in Iceland

\begin{tabular}{|l|c|}
\hline Chi-square (d.f. 136)—null & 650.23 \\
\hline Chi-square (d.f. 119)—-model & 266.91 \\
\hline Chi-square_model / d.f. & 2.24 \\
\hline GFI & .65 \\
\hline AGFI & .55 \\
\hline RMSR & .12 \\
\hline Number of item loadings statistically significant at p <.05 & All 17 items \\
\hline Composite reliability (coeff. Alpha) & .895 \\
\hline Variance extracted & $38.89 \%$ \\
\hline
\end{tabular}

Following the confirmation of the single-factor model for the CETSCALE, the degree of consumer ethnocentrism in Iceland could be computed as the average score of the 17 items. The average ethnocentrism score for the sample was found to be moderate at 3.526 (on a 7-point scale), with a standard deviation of 1.006. Previous research (Han, 1988) has indicated that older people are likely to exhibit higher levels of ethnocentrism, as they tend to be more conservative. In our study too, ethnocentrism had a significantly positive correlation of .284 ( $p<.05$ ) with respondent age, indicating that ethnocentrism increased with age in Icelandic consumers. Another finding from previous research (Howard, 1989) was that women tended to be more ethnocentric than men. In our study, however, no statistically significant difference was found between the ethnocentrism scores of men $($ score $=3.323$, s.d. $=$ $1.049, \mathrm{n}=24)$ and women $($ score $=3.627, \mathrm{~s} . \mathrm{d} .=.979, \mathrm{n}=48)$ from a $\mathrm{t}$-test $(\mathrm{t}=1.212, \mathrm{p}=.229)$. Thus, we could not conclude that the level of ethnocentrism was different between men and women in Iceland.

\section{Ethnocentrism and Country Image}

Ethnocentrism is expected to lead to more positive evaluations of one's own country (Sharma, Shimp, and Shin, 1995). The ethnocentrism measure was correlated with the measures of country image for all five countries in the study, and the results are shown in Table 2. Ethnocentrism was found to have a significantly positive correlation $(.270$ at $\mathrm{p}=.022)$ with the image of the home country, Iceland. The correlations of ethnocentrism with the images of the four other countries were non-significant. This indicated that while ethnocentrism definitely led to a more positive perception of the home country, it did not necessarily lead to a negative perception of the other countries. 
Table 2

Correlation of Ethnocentrism with Country Image

\begin{tabular}{|l|c|c|}
\hline & Correlation Coefficient & Statistical Significance (p) \\
\hline USA country image & .006 & .963 \\
\hline UK country image & .044 & .716 \\
\hline Holland country image & .065 & .585 \\
\hline Denmark country image & .061 & .613 \\
\hline Iceland country image & $\mathbf{. 2 7 0}$ & $\mathbf{. 0 2 2}$ \\
\hline
\end{tabular}

Statistically significant correlations $(\mathrm{p}<.05)$ are indicated in bold

\section{Country Image and Product Evaluation}

The literature suggested the likelihood of product evaluations being influenced by country stereotyping (Chattalas, Kramer, and Takada, 2008). To examine the predicted relationship between the perceived image of a country and the evaluation of products from that country, correlation coefficients were computed between the image of each country and the measures for quality, value, and image of products from that country. Only these three variables were considered for the correlation analysis as these variables (product quality, value, and image) were truly perceptual measures, whereas the other two measures in the study, product availability and promotion, were based more on objective information (how easily are products available in the market, or how intensely are products advertised) than perception. The correlations are presented in Table 3.

Table 3

Relationship of Country Image with Product Evaluation

\begin{tabular}{|l|c|c|c|}
\hline \multirow{2}{*}{ Country } & \multicolumn{3}{|c|}{ Correlation of country image with: } \\
\cline { 2 - 4 } & Product Quality & Product Value & Product Image \\
\hline USA & $\mathbf{. 5 2 9}$ & .049 & .022 \\
\hline UK & $\mathbf{. 3 5 4}$ & .063 & .146 \\
\hline Holland & $\mathbf{. 5 0 4}$ & .176 & $\mathbf{3 0 6}$ \\
\hline Denmark & $\mathbf{. 6 3 5}$ & .121 & $\mathbf{. 4 1 4}$ \\
\hline Iceland & $\mathbf{. 3 5 1}$ & $\mathbf{. 3 1 7}$ & $\mathbf{. 3 7 8}$ \\
\hline
\end{tabular}

Statistically significant correlations (at the $\mathrm{p}<.05$ level) are denoted in bold

It is seen from Table 3 that perceived product quality is significantly correlated $(\mathrm{p}=<.05$ or beyond) with perceived country image for all five countries. The perceived product value (i.e., price relative to quality) was significantly related with country image only for Iceland. The perceived product image was significantly related with country image for Iceland, Holland, and Denmark, but no significant correlation was found between product image and country image for the United States and the United Kingdom. Thus, there was partial support for the expected relationship between country image and the various dimensions of product evaluation. In particular, there was strong support for the positive relationship between country image and perceived product quality, since this relationship was found to be significant for all countries.

\section{Impact of Ethnocentrism and Other Factors on Buying Intention}

The eventual purpose of measuring consumer ethnocentrism, country image and the various product- and marketing-related facets was to investigate the influence of all these factors on the consumer's intention to purchase products originating from various countries. A linear regression model was tested for this purpose, where the Icelandic consumers' intention to buy food products made domestically and those imported from the United States, the United Kingdom, Holland, and Denmark was the dependent variable, while ethnocentrism, and perceived product quality, value, image, availability, promotion, and country image for the five countries in question were the independent variables. Thus, five separate regression models were tested (one for each country). The parameter estimates are presented in Table 4. 
Table 4

Regression of Icelandic Consumers' Intention to Buy Products from Various Countries on Ethnocentrism and Other Relevant Variables

\begin{tabular}{|c|c|c|c|c|c|c|c|c|c|c|c|c|c|c|c|}
\hline & \multicolumn{15}{|c|}{ Dependent variable: Icelandic consumers' intention to buy products from: } \\
\hline & \multicolumn{3}{|c|}{ USA } & \multicolumn{3}{|c|}{ UK } & \multicolumn{3}{|c|}{ Holland } & \multicolumn{3}{|c|}{ Denmark } & \multicolumn{3}{|c|}{ Iceland } \\
\hline & $\begin{array}{c}\text { Std. } \\
\beta\end{array}$ & $\begin{array}{c}\mathrm{t}- \\
\text { value }\end{array}$ & $\mathbf{p}$ & $\begin{array}{c}\text { Std. } \\
\beta\end{array}$ & $\begin{array}{c}\mathrm{t}- \\
\text { value }\end{array}$ & $\mathbf{p}$ & $\begin{array}{c}\text { Std. } \\
\beta\end{array}$ & $\begin{array}{c}\mathrm{t}- \\
\text { value }\end{array}$ & $\mathbf{p}$ & $\begin{array}{c}\text { Std. } \\
\beta\end{array}$ & $\begin{array}{c}\mathrm{t}- \\
\text { value }\end{array}$ & $\mathbf{p}$ & $\begin{array}{c}\text { Std. } \\
\beta\end{array}$ & $\begin{array}{c}\mathrm{t}- \\
\text { value }\end{array}$ & $\mathbf{p}$ \\
\hline Product Quality & .33 & 2.74 & .01 & .51 & 4.19 & .00 & .60 & 4.82 & .00 & .56 & 3.63 & .00 & .80 & 8.59 & .00 \\
\hline Product Value & .16 & 1.60 & .12 & .14 & 1.32 & .19 & .13 & 1.44 & .15 & .02 & .17 & .86 & .26 & 3.10 & .00 \\
\hline Product Image & .09 & .90 & .37 & .11 & .98 & .33 & .04 & .34 & .73 & .07 & .54 & .59 & .11 & 1.21 & .23 \\
\hline $\begin{array}{l}\text { Product } \\
\text { Availability }\end{array}$ & .20 & 1.78 & .08 & .10 & .86 & .39 & .32 & 3.14 & .00 & .20 & 1.70 & .09 & .19 & 2.44 & .02 \\
\hline $\begin{array}{l}\text { Product } \\
\text { Promotion }\end{array}$ & .48 & 4.16 & .00 & .38 & 3.08 & .00 & .30 & 2.87 & .01 & .03 & .24 & .80 & .10 & 1.09 & .24 \\
\hline Country Image & .08 & .70 & .48 & .42 & 3.45 & .00 & .46 & 3.76 & .00 & .27 & 1.81 & .07 & .01 & .07 & .94 \\
\hline Ethnocentrism & -.21 & -2.23 & .03 & -.06 & -.63 & .53 & -.07 & -.79 & .43 & -.12 & -1.10 & .27 & .03 & .35 & .73 \\
\hline Adjusted $\mathrm{R}^{2}$ & \multicolumn{3}{|c|}{.445} & \multicolumn{3}{|c|}{.373} & \multicolumn{3}{|c|}{.484} & \multicolumn{3}{|c|}{.323} & \multicolumn{3}{|c|}{.640} \\
\hline Model F-value & \multicolumn{3}{|c|}{7.317} & \multicolumn{3}{|c|}{5.448} & \multicolumn{3}{|c|}{10.509} & \multicolumn{3}{|c|}{4.356} & \multicolumn{3}{|c|}{16.257} \\
\hline $\begin{array}{l}\text { Model } \\
\text { Significance (p) }\end{array}$ & \multicolumn{3}{|c|}{.000} & \multicolumn{3}{|c|}{.000} & \multicolumn{3}{|c|}{.000} & \multicolumn{3}{|c|}{.001} & \multicolumn{3}{|c|}{.000} \\
\hline
\end{tabular}

For the independent variables, statistically significant $\mathrm{p}$-values $(\mathrm{p}<.05)$ are denoted in bold

It is seen from Table 4 that the regression model is statistically significant for all five countries, with the Fvalue of the model ranging from 4.356 to 16.257 ( $\mathrm{p} \leq .001$ in all cases). The impact of the various independent variables was not similar for all five countries, however, as indicated by the statistical significance of different variables (in terms of the $p$-values of the t-statistics of the standardized $\beta$-coefficients) for the five countries. Product quality had a significantly positive influence on buying intention for products from all five countries. Perceived product value had a significantly positive impact on buying intention for food products only from the home country (Iceland), while perceived product image, as a single factor in the model, did not have a statistically significant impact on the buying intention for food products originating from any of the five countries. Product availability had a significant influence on the intention to buy food products from Holland and Iceland. Product promotion influenced the intention of Icelandic consumers to buy food products from all countries, except Denmark. Perceived country image positively influenced the intention to buy food products imported only from the United Kingdom and Holland. Ethnocentrism in Icelandic consumers had a negative influence on the intention to buy food products from the United States, but did not impact the intention to buy food products from other countries on its own.

\section{MANAGERIAL IMPLICATIONS}

The results of the study offer several managerial implications for marketers of domestic and imported food products in Iceland. Product quality is the single common factor that positively influences Icelandic consumers' intention to buy food products from any country. Therefore, to successfully compete in the Icelandic market, food product marketers must emphasize the quality of their products first and foremost. Product value (i.e., the perception of price relative to quality) influences purchase intention for domestic food products only. Hence, marketers of domestically-made food products in Iceland should also focus on keeping prices low while maintaining quality (an already established significant factor). Since perceived product value does not influence the intention to buy food products imported from the other four countries, domestic food marketers will be hard-pressed to increase the perceived value of their products by maintaining lower prices while not sacrificing quality (as quality influences the intention to buy products from all countries) to gain a competitive advantage. The fact that product image (prestigiousness and attractiveness) is not an influencer of buying intention for any country indicates the relative irrelevance of product image in the buying decision for a routinely purchased and generally non-expensive necessity product such as food. 
Perceived country image (of the country of product origin) is a significant influencer of buying intention for food products from the United Kingdom and Holland. Country image also has a significant positive relationship with perceived product quality for all five countries (from Table 3) and, as already seen, perceived product quality significantly affects the buying intention of products from all countries. Therefore, marketers of food products from all countries should be careful that a positive image of the country-of-origin is presented to Icelandic consumers, and British and Dutch exporters of food products to Iceland need to emphasize this even more. Now, the United Kingdom and Holland are also two countries for which promotion has a significant impact on buying intention (as seen from Table 4). Hence, marketers of British and Dutch food products in Iceland will have a particular opportunity to positively promote the images of the two countries through appropriate advertising and publicity, and further improve their chances of positively influencing consumers' buying intention.

Another country for which product promotion has a positive influence on buying intention is the United States. Thus, American food product exporters to Iceland should focus on increasing the promotional intensity to positively affect the buying intention of consumers. Since perceived product quality is also a direct influencer of buying intention, marketers of American food products may particularly emphasize quality in their advertising campaigns in Iceland. The opportunity for American marketers to influence buying intention through increasing promotional intensity is also relevant from the perspective of increasing consumer awareness of American food products in Iceland, as such awareness might be initially low due to the fact that Iceland currently imports a much lower volume of food products from the United States compared to the volume imported from the three European countries.

The positive influence of product availability on consumers' buying intention is observed for only two countries-Iceland and Holland. It is obviously expected that domestic food product marketers will be able to distribute their products more efficiently and effectively in the home market. Dutch food product exporters should make a note of the possibility of improving Icelandic consumers' buying intention by improving distribution and making their products more easily available, because the regression model suggests that this could be a way for them to gain competitive advantage over American, British, and Danish marketers (for whom product availability has no significant impact on buying intention).

Ethnocentrism directly and negatively influences Icelandic consumers' intention to buy food products from only one country - the United States. There does not seem to be much that American exporters can do about it, since ethnocentrism is a characteristic of the consumers and is not a variable that can be directly controlled by marketers. However, American exporters might be able to offset the negative impact of ethnocentrism by increasing promotional intensity and thereby increasing the perception of quality since both promotion and product quality have a positive influence on Icelandic consumers' buying intention of American food products.

\section{CONCLUSION}

This exploratory study provides some initial insights into consumer ethnocentrism and product country-oforigin perceptions of consumers in Iceland. Food was used as the product category in this study. Caution should be exercised in generalizing the results across all product categories, as the product category is a salient factor in product country-of-origin evaluations (Papadopoulos and Heslop, 1993). Food product marketers from the United States, the United Kingdom, Holland, and Denmark can assess their current competitive situation in terms of various marketing-related dimensions (product quality, value, image, availability, and promotional effectiveness) in the promising Icelandic market. Future research should include countries other than the ones featured in the present study, as the Icelandic market and its affluent population would attract marketers from many different countries.

\section{AUTHOR INFORMATION}

Soumava Bandyopadhyay is a professor of marketing at Lamar University, U.S.A. His areas of research interest include cross-cultural and global marketing, Internet-based marketing, and channels of distribution. E-mail: soumava.bandyopadhyay@lamar.edu. 


\section{REFERENCES}

1. Carmines, E. \& McIver, J. (1981). Analyzing Models with Unobservable Variables: Analysis of Covariance Structures. In Bohrnstedt, G. \& Borgatta, E. (Eds.), Social Measurement: Current Issues, 65115, Beverly Hills: Sage Publications.

2. Chattalas, M., Kramer, T. \& Takada, H. (2008). The Impact of National Stereotypes on the Country of Origin Effect: A Conceptual Framework. International Marketing Review, 25 (1), 54-74.

3. Durvasula, S., Andrews, J.C. \& Netemeyer, R.G. (1997). A Cross-Cultural Comparison of Consumer Ethnocentrism in the United States and Russia. Journal of International Consumer Marketing, 9 (4), 73-93.

4. Evanschitzky, H., Wangenheim, F., Woisetscläger, D. \& Blut, M. (2008). Consumer Ethnocentrism in the German market. International Marketing Review, 25 (1), 7-32.

5. Han, C.M. (1988). The Role of Consumer Patriotism in the Choice of Domestic Versus Foreign Products. Journal of Advertising Research, 28 (3), 25-32.

6. Howard, D.G. (1989). Understanding How American Consumers Formulate Their Attitudes About Foreign Products. Journal of International Consumer Marketing, 2 (2), 7-24.

7. Jöreskog, K. \& Sörbom, D. (1993). LISREL: Analysis of Linear Structural Relationships by the Method of Maximum Likelihood, Version VIII. Chicago: National Education Resources.

8. Josiassen, A. (2011). Consumer Disidentification and Its Effects on Domestic Product Purchases: An Empirical Investigation in the Netherlands. Journal of Marketing, 75 (2), 124-140.

9. Katsioloudes, M.I., Thoradottir, S. \& Balsmeier, P.W. (1996). Iceland Drifting Towards International Integration: The Pros and Cons of Joining the EU. International Journal of Commerce and Management, 6 (3/4), 41-56.

10. Klein, J.G., Ettenson, R. \& Krishnan, B. (2006). Extending the Construct of Consumer Ethnocentrism: When Foreign Products are Preferred. International Marketing Review, 23 (3), 304-321.

11. Klein, J.G., Ettenson, R. \& Morris, M.D. (1998). The Animosity Model of Foreign Product Purchase: An Empirical Test in the People's Republic of China. Journal of Marketing, 62 (1), 89-100.

12. Lundberg, L. (1992). European Economic Integration and the Nordic Countries' Trade. Journal of Common Market Studies, 30 (2), 157-173.

13. Papadopoulos, N. \& Heslop, L.A. (1993). Product-Country Images: Impact and Role in International Marketing. New York: International Business Press

14. Pisharodi, R.M. \& Parameswaran (1992). Confirmatory Factor Analysis of a Country-of-Origin Scale: Initial Results. Advances in Consumer Research, 19, 706-714.

15. Poon, P., Evangelista, F. \& Albaum, G. (2010). Attitudes of Migrants Towards Foreign-Made Products: An Exploratory Study of Migrants in Australia. Journal of Consumer Marketing, 27 (1), 35-42.

16. Schneider, D. (2005). The Psychology of Stereotyping. New York: Guilford Press.

17. Shankarmahesh, M.N. (2006). Consumer Ethnocentrism: An Integrative Review of Its Antecedents and Consequences. International Marketing Review, 23 (2), 146-172.

18. Sharma, S., Shimp, T.A. \& Shin, J. (1995). Consumer Ethnocentrism: A Test of Antecedents and Moderators. Journal of the Academy of Marketing Science, 23 (1), 26-37.

19. Shimp, T.A. \& Sharma, S. (1987). Consumer Ethnocentrism: Construction and Validation of the CETSCALE. Journal of Marketing Research, 24 (3), 280-289.

20. Statistics Iceland (2011). Online at http://www.statice.is

21. Suh, T. \& Kwon, I.G. (2002). Globalization and Reluctant Buyers. International Marketing Review, 19 (6), 663-680.

22. Tait, N. (2010). EU Gives Go-Ahead for Iceland Entry Talks. The Financial Times, July 26, London.

23. Tse, D.K. \& Gorn, G. (1993). An Experiment on the Salience of Country-of-Origin in the Era of Global Brands, Journal of International Marketing, 1 (1), 57-76.

24. Vida, I. \& Reardon, J.. (2008). Domestic Consumption: Rational, Affective, or Normative Choice? Journal of Consumer Marketing, 25 (1), 34-44.

25. World Bank (2011). Online at http://data.worldbank.org/country/iceland. 


\section{APPENDIX}

Description of Scale Items

Every item on every scale is a 7 -point measure, where $1=$ strongly disagree, and $7=$ strongly agree.

Consumer Ethnocentrism: CETSCALE by Shimp and Sharma [17]

1. Icelandic people should always buy Icelandic-made products instead of imports.

2. Only those products that are unavailable in Iceland should be imported.

3. Buy Icelandic-made products. Keep Iceland working.

4. Icelandic products first, last, and foremost.

5. Purchasing foreign-made products is un-Icelandic.

6. It is not right to purchase foreign products.

7. An Icelander should always buy Icelandic-made products.

8. We should purchase products manufactured in Iceland instead of letting other countries get rich off us.

9. It is always best to purchase Icelandic products.

10. There should be very little trading or purchasing goods from other countries unless out of necessity.

11. Icelanders should not buy foreign products because this hurts Iceland's business and causes unemployment.

12. Curbs should be put on all imports.

13. It may cost me in the long run, but I prefer to support Icelandic products.

14. Foreigners should not be allowed to put their products in Icelandic markets.

15. Foreign products should be taxed heavily to reduce their entry into Iceland.

16. We should buy from foreign countries only those products that we cannot obtain within our own country.

17. Icelandic consumers who purchase products made in other countries put their follow Icelanders out of work.

Product Quality

1. Food products from this country are of high quality.

2. Food products from this country taste good.

3. Eating food products from this country leads to good health.

4. Food products from this country are nutritious.

Product Value

1. Food products from this country are unreasonably expensive (reverse scored).

2. Food products from this country are priced reasonably compared to quality.

\section{Product Image}

1. Food products from this country are not attractive (reverse scored)

2. Food products from this country are prestigious.

\section{Product Availability}

1. Food products from this country are easily available.

2. Food products from this country are sold in many countries.

\section{Product Promotion}

1. Food products from this country are heavily advertised.

2. Information on food products from this country is easily available.

\section{Country Image}

1. People in this country have a high standard of living.

2. People of this country are hard-working.

3. People of this country enjoy good health.

Buying Intention

1. I intend to buy food products coming from this country. 